\title{
Application of ZnO Nanoparticles EM Wave Detector Prepared by Sol- gel and Self-Combustion Techniques
}

\author{
Noorhana Yahya ${ }^{1}$, Hanita Daud ${ }^{1}$, Nurulhuda Ali Tajuddin ${ }^{2}$, \\ Hasnah Mohd Daud ${ }^{1}$, Afza Shafie ${ }^{1}$ and Poppy Puspitasari ${ }^{2}$ \\ ${ }^{1}$ Fundamental and Applied Sciences Department, Universiti Teknologi PETRONAS \\ 31750 Bandar Seri Iskandar, Tronoh, Perak, Malaysia \\ ${ }^{2}$ Electrical and Electronic Engineering Department, Universiti Teknologi PETRONAS \\ 31750 Bandar Seri Iskandar,Tronoh, Perak, Malaysia \\ noorhana_yahya@petronas.com.my
}

Keywords: Zinc oxide, sol-gel technique, self-combustion technique

\begin{abstract}
Zinc oxide ( $\mathrm{ZnO})$ has found many important applications such as optoelectronic devices, sensors and varistors. The challenging part however is synthesizing $\mathrm{ZnO}$ nanoparticles and its utilisation as EM detectors. Sol-gel and self-combustion techniques were chosen in this study due to the ability to produce single phase and nano-size samples. The starting mixture consists of 10 grams of zinc (II) nitrate, $\mathrm{Zn}\left(\mathrm{NO}_{3}\right)_{2} .6 \mathrm{H}_{2} \mathrm{O}$ salt which was dissolved in $50 \mathrm{~mL}$ of nitric acid, $\mathrm{HNO}_{3}$. The solution was stirred at $250 \mathrm{rpm}$ continuously for 1 day. The mixture was then gradually heated for every 15 minutes until it combusted at $110^{\circ} \mathrm{C}$ for the self-combustion technique. For the sol-gel technique, the dissolved mixture was heated at $40^{\circ} \mathrm{C}, 50^{\circ} \mathrm{C}, 60^{\circ} \mathrm{C}$ and $70^{\circ} \mathrm{C}$ until the gelatine was formed. After the drying process, the as-prepared samples were annealed at $100^{\circ} \mathrm{C}$ and $200{ }^{\circ} \mathrm{C}$ for 1 hour for each technique. Characterizations were performed by using X-Ray Diffraction (XRD), Raman Spectra and Scanning Electron Microscopy (SEM).The XRD analysis showed a major peak of [101] plane at $2 \Theta$ for the self-combustion technique and the sol-gel technique. Raman results for the samples prepared via sol-gel and self-combustion techniques had shown the major peak of $\mathrm{ZnO}$ that is located at the Raman shifts of $437.67 \mathrm{~cm}^{-1}$. Using the Scherrer equation, single crystal nano particle of $\mathrm{ZnO}$ was successfully obtained in the range of $38.49 \mathrm{~nm}$ to $50.70 \mathrm{~nm}$ for the sample prepared via the sol gel technique. By the self-combustion technique, the average dimension of the as-prepared sample is in the range of 34-49 $\mathrm{nm}$. Further heat treatment resulted in a major change of the Raman shift corresponding to the single phase $\mathrm{ZnO}$ nano particles. The best samples were used as electromagnetic (EM) detectors. The EM detectors are polymer based composite which were prepared using a casting technique.
\end{abstract}

\section{Introduction}

Zinc oxide is a unique and very useful material to date. Zinc oxide has a stable wurtzite structure with a lattice spacing $\mathrm{a}=0.325 \mathrm{~nm}$ and $\mathrm{c}=0.521 \mathrm{~nm}$ [1]. Various $\mathrm{ZnO}$ nanostructures with different morphologies such as nanorods [2,3], nanotubes [4], nanosphere [5], nanoneedles [6] etc have been reported. These nanostructures have been fabricated with different methods such as hydrothermal $[1,7,8]$, precipitation [9], sol-gel [5,6,10], simple thermal sublimation [11], selfcombustion [12], vapour liquid solid [3,13], double jet precipitation [14], polymerized complex method [15], polyol method [16] etc. Zinc oxide nanostructure materials can be used for devices like solar cells, sensors, detectors and energy generators [7] and other transparent conducting oxides [17]. $\mathrm{ZnO}$ has optically excellent properties such as a wide band gap $(3.37 \mathrm{eV})[1,4,18]$ and a large exciton binding energy $(60 \mathrm{meV})$ at room temperature $[1,4]$. ZnO has electrical properties and a 
band gap energy similar to $\mathrm{TiO}_{2}$ and it has been reported sometimes to be more efficient than $\mathrm{TiO}_{2}$ [5]. The lowest resistivity, $0.2 \Omega \mathrm{m}$, was obtained for pure $\mathrm{ZnO}$ after annealing in $\mathrm{Ar}$ [10]. In addition, $\mathrm{ZnO}$ is on the borderline between a semiconductor and an ionic material [12]. The chemical reduction of crystal yields oxygen vacancies which act as donors and current voltage characterization of $\mathrm{ZnO}$ single crystals at $77 \mathrm{~K} \mathrm{[19]}$. This would be the basis of our intention of using $\mathrm{ZnO}$ particles as EM detectors. This paper reports novel synthesis techniques, sol-gel and self combustion and their physical characterization. Both the sol-gel and the self-combustion are powerful methods for tailoring transition metal oxides for detection applications [5]. The ZnO nanoparticles are used as electromagnetic (EM) detectors.

\section{Experimental procedures}

Synthesis of ZnO Nanoparticles. ZnO nanoparticles were prepared by employing two techniques, which are the sol-gel and self-combustion techniques. This process began with dissolving zinc nitrate, $\mathrm{Zn}\left(\mathrm{NO}_{3}\right)_{2} \cdot 6 \mathrm{H}_{2} \mathrm{O}$ salt into $65 \%$ concentrated nitric acid, $\mathrm{HNO}_{3}$ solution for each technique. Both solutions were stirred for 1 day to form a homogeneous sol. For sol-gel, the homogenized sol solution was then heated up at $40^{\circ} \mathrm{C}, 50^{\circ} \mathrm{C}, 60^{\circ} \mathrm{C}$ and $70^{\circ} \mathrm{C}$ until the gelatin was formed. Meanwhile, the homogenized sol solution was also heated until it combusted at $110^{\circ} \mathrm{C}$ for the self-combustion technique. Both samples were dried in an oven at $110^{\circ} \mathrm{C}$ for 24 hours. The dried samples were crushed for 1 hour to obtain fine particles. After the crushing process, the green powders were annealed at $100^{\circ} \mathrm{C}, 200^{\circ} \mathrm{C}, 300^{\circ} \mathrm{C}$ and $400^{\circ} \mathrm{C}$ [21] for 1 hour for both techniques.

Synthesis of EM detector ( Polyvinyl Alcohol + as-prepared ZnO). The starting mixture consists of $3.6 \mathrm{~g}$ of PVA powder which was dissolved in $160 \mathrm{~mL}$ of deionizer water. The solution was manually stirred at $60^{\circ} \mathrm{C}$ until the PVA powder was dissolved. The thick solution was divided into two parts, the first part consists of pure PVA and the second part consists of PVA $+\mathrm{ZnO}$ (sol-gel powder, annealed at $300^{\circ} \mathrm{C}$ ). All the samples were placed in a petri dish. Later, the samples were dried under a spotlight for about 12 hours. The dried polymers were cut into rectangular shape with the size of $6.5 \mathrm{~cm} \times 2.5 \mathrm{~cm}$. The average thickness of the samples is approximately $0.04 \mathrm{~mm}$.

Characterization of Particles. The samples were then characterized by X-Ray Diffraction (XRD), Raman Spectra and Scanning Electron Microscopy (SEM). Characterization of zinc oxide is to obtain information about its crystallinity and morphology [12]. The energy dispersive technique was used to give the elementary analysis of the $\mathrm{ZnO}$ annealed powder. The electromagnetic detection set up was published elsewhere [20].

\section{Results and discussion}

X-Ray Diffractions (XRD). Figure 1 and Figure 2 show the XRD patterns of the as-prepared ZnO samples that were prepared by sol-gel and self combustion techniques, respectively. All peaks appeared are matched with a standard card, for each of the samples at annealed $100^{\circ} \mathrm{C}, 200^{\circ} \mathrm{C}$, $300^{\circ} \mathrm{C}$ and $400^{\circ} \mathrm{C}$ by using both techniques (Table 1 ). 
Table 1. Standard Card of Zinc Oxide.

\begin{tabular}{|c|c|}
\hline Sample & Standard Card \\
\hline $\mathrm{ZnO} \mathrm{SG}\left(100^{\circ} \mathrm{C}\right)$ & SS-NNNN 72-0627 \\
\hline $\mathrm{ZnO} \mathrm{SG}\left(200^{\circ} \mathrm{C}\right)$ & SS-NNNN 89-0511 \\
\hline $\mathrm{ZnO} \mathrm{SG(300^{ \circ } \mathrm { C } )}$ & SS-NNNN 65-3411 \\
\hline $\mathrm{ZnO} \mathrm{SG}\left(400^{\circ} \mathrm{C}\right)$ & SS-NNNN 79-2205 \\
\hline $\mathrm{ZnO} \mathrm{SC}\left(100^{\circ} \mathrm{C}\right)$ & SS-NNNN 89-1397 \\
\hline $\mathrm{ZnO} \mathrm{SC}\left(200^{\circ} \mathrm{C}\right)$ & SS-NNNN 79-2205 \\
\hline $\mathrm{ZnO} \mathrm{SC}\left(300^{\circ} \mathrm{C}\right)$ & SS-NNNN 89-0511 \\
\hline $\mathrm{ZnO} \mathrm{SC}\left(400^{\circ} \mathrm{C}\right)$ & SS-NNNN 89-0510 \\
\hline
\end{tabular}

The samples prepared by the sol-gel method show the [101] major peak at $2 \theta$ of $9.33^{\circ}, 36.29^{\circ}$ and $36.27^{\circ}, 36.29^{\circ}$ which was annealed at $100^{\circ} \mathrm{C}, 200^{\circ} \mathrm{C}, 300^{\circ} \mathrm{C}$ and $400^{\circ} \mathrm{C}$, respectively. Meanwhile for the self-combustion method, the [101] major peak was observed at $2 \theta$ of $36.18^{\circ}, 36.26^{\circ}, 36.29^{\circ}$ and $36.27^{\circ}$ for samples that were annealed at $100^{\circ} \mathrm{C}, 200^{\circ} \mathrm{C}, 300^{\circ} \mathrm{C}$ and $400^{\circ} \mathrm{C}$, respectively. This result is consistent with other research done [12].

By applying the Scherrer equation [12,14], which is given in Equation [1], the average crystallite size can be obtained:

$$
D=\frac{0.89 \lambda}{\beta \cos \vartheta}
$$

where: $\lambda$ is the $\mathrm{X}$-ray wavelength, $\theta$ is the Bragg diffraction angle, $\beta$ is the peak width at halfmaximum.

The average crystallite size of the $\mathrm{ZnO}$ samples that were prepared via the sol-gel method annealed at $100^{\circ} \mathrm{C}$ and $200^{\circ} \mathrm{C}$ are $38.49 \mathrm{~nm}$ and $50.70 \mathrm{~nm}$ respectively. But when the annealing temperature increased to $300^{\circ} \mathrm{C}$, there was a slight decrease in the crystal size (Table 1). For the self-combustion technique, the average crystallite size is $34.58 \mathrm{~nm}$ for a sample annealed at $100^{\circ} \mathrm{C}$ and $48.63 \mathrm{~nm}$ for a sample annealed at $200^{\circ} \mathrm{C}$ (Table 1). Referring to the Full Width Half Maximum (FWHM) values, it is obvious that all of the as- prepared samples exhibit larger values indicating smaller particle size. 


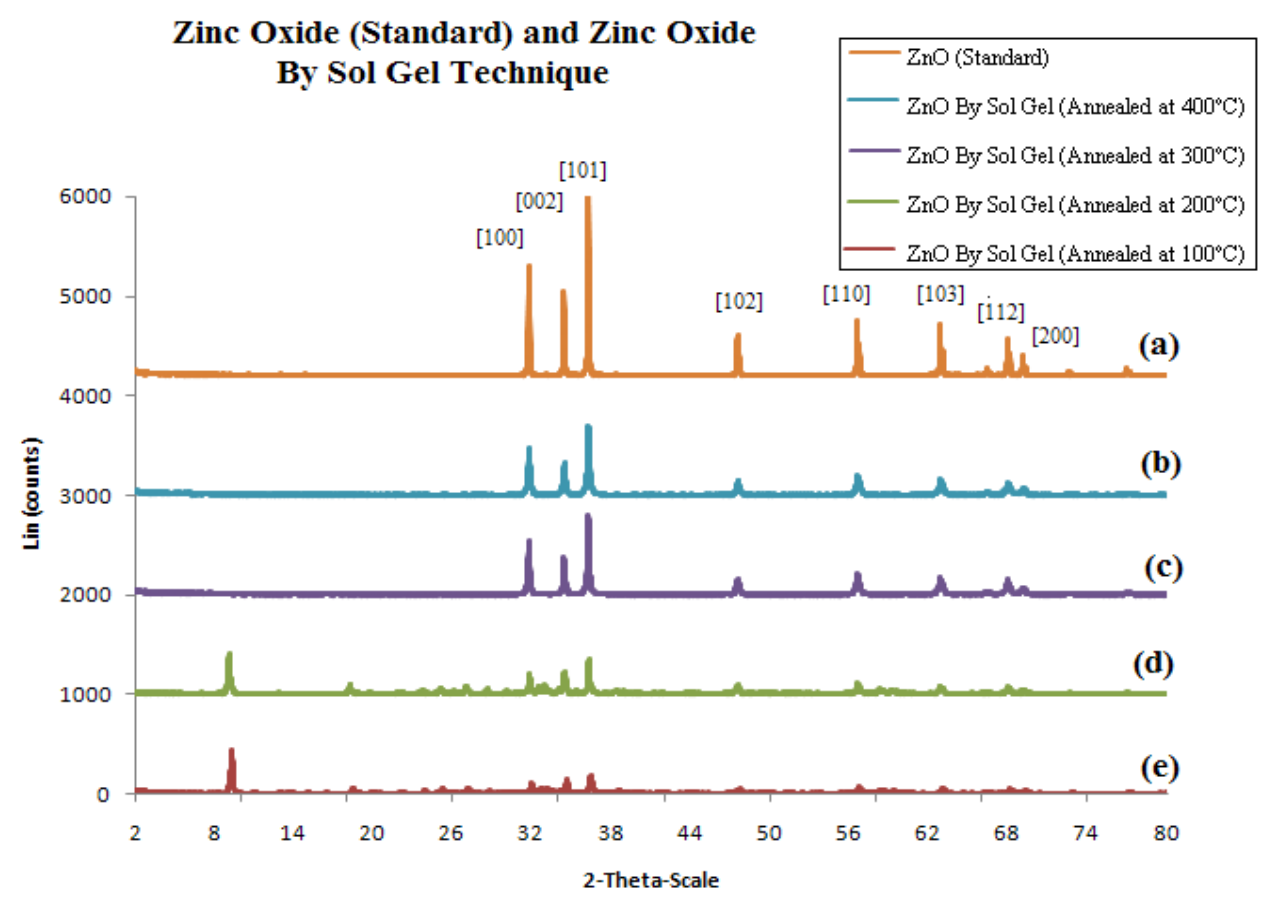

Figure 1. XRD patterns of as-synthesized zinc oxide samples with a major peak [101] (a) zinc oxide standard; and samples prepared via sol gel technique that were annealed at (b) $400^{\circ} \mathrm{C}$ and (c) $300^{\circ} \mathrm{C}$ (c) $200^{\circ} \mathrm{C}$ and (d) $100^{\circ} \mathrm{C}$.

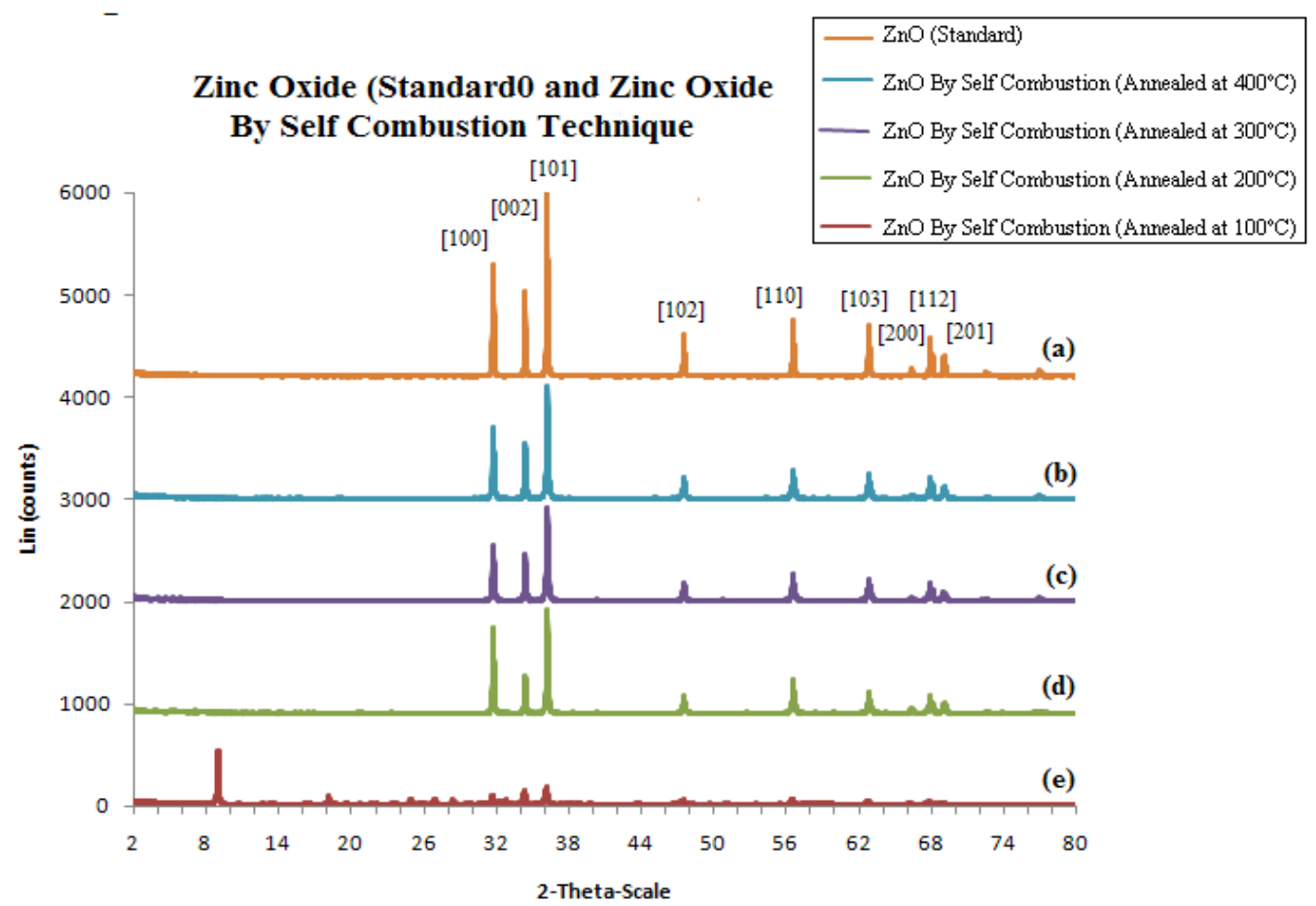

Figure 2. XRD patterns of as-synthesized zinc oxide samples with a major peak [101]; (a) zinc oxide standard; and samples prepared via the self combustion technique that were annealed at (b) $400^{\circ} \mathrm{C}$ and (c) $300^{\circ} \mathrm{C}$ (d) $200^{\circ} \mathrm{C}(\mathrm{e}) 100^{\circ} \mathrm{C}$. 
Table 1. XRD and RAMAN Results.

\begin{tabular}{|c|c|c|c|c|c|c|c|c|c|}
\hline \multirow[b]{2}{*}{ Samples } & \multicolumn{7}{|c|}{ X-Ray Diffraction } & \multicolumn{2}{|c|}{$\begin{array}{c}\text { Raman } \\
\text { Spectroscopy }\end{array}$} \\
\hline & $\begin{array}{l}\text { Intensity } \\
\text { (Counts) }\end{array}$ & FWHM & $\begin{array}{c}\text { d- } \\
\text { spacing } \\
(\AA)\end{array}$ & $\begin{array}{l}\text { Crystallite } \\
\text { size }(\mathrm{nm})\end{array}$ & A & b & $\mathrm{c}$ & $\begin{array}{c}\text { Raman } \\
\text { Sift }\left(\mathrm{cm}^{-1}\right)\end{array}$ & $\begin{array}{l}\text { Intensity } \\
\text { (Counts) }\end{array}$ \\
\hline $\begin{array}{c}\mathrm{ZnO} \\
\mathrm{SG}\left(100^{\circ} \mathrm{C}\right)\end{array}$ & 9.332 & 0.222 & 9.469 & 38.490 & 19.48 & 6.238 & 5.517 & 1055.300 & 42.140 \\
\hline $\begin{array}{c}\mathrm{ZnO} \\
\mathrm{SG}\left(200^{\circ} \mathrm{C}\right)\end{array}$ & 36.287 & 0.163 & 2.473 & 50.700 & 3.249 & 3.249 & 5.205 & 1055.300 & 36.569 \\
\hline $\begin{array}{c}\mathrm{ZnO} \\
\mathrm{SG}\left(300^{\circ} \mathrm{C}\right)\end{array}$ & 36.269 & 0.201 & 2.474 & 33.290 & 3.249 & 3.249 & 5.269 & 439.696 & 55.048 \\
\hline $\begin{array}{c}\mathrm{ZnO} \\
\mathrm{SG}\left(400^{\circ} \mathrm{C}\right)\end{array}$ & 36.285 & 0.216 & 2.4737 & 38.290 & 3.250 & 3.250 & 5.207 & 438.177 & 43.830 \\
\hline $\begin{array}{c}\mathrm{ZnO} \\
\mathrm{SC}\left(100^{\circ} \mathrm{C}\right)\end{array}$ & 36.178 & 0.239 & 2.480 & 34.580 & 3.253 & 3.253 & 5.213 & 437.670 & 28.438 \\
\hline $\begin{array}{c}\mathrm{ZnO} \\
\mathrm{SC}\left(200^{\circ} \mathrm{C}\right)\end{array}$ & 36.264 & 0.170 & 2.475 & 48.630 & 3.250 & 3.250 & 5.207 & 437.670 & 20.186 \\
\hline $\begin{array}{c}\mathrm{ZnO} \\
\mathrm{SC}\left(300^{\circ} \mathrm{C}\right)\end{array}$ & 36.269 & 0.186 & 2.474 & 44.450 & 3.249 & 3.249 & 5.205 & 433.115 & 20.087 \\
\hline $\begin{array}{c}\mathrm{ZnO} \\
\mathrm{SC}\left(400^{\circ} \mathrm{C}\right)\end{array}$ & 36.271 & 0.175 & 2.474 & 47.240 & 3.248 & 3.248 & 5.205 & 440.203 & 46.515 \\
\hline $\begin{array}{c}\mathrm{ZnO} \\
\text { (Standard) }\end{array}$ & 36.251 & 0.113 & 2.476 & n.a & 3.250 & 3.250 & 5.207 & 437.171 & 31.5891 \\
\hline
\end{tabular}

n.a: not available

Raman Spectra. Based on the Raman spectroscopy results, the intensity of the Raman shift of the zinc oxide samples decreases when the annealing temperature was increased to $200^{\circ} \mathrm{C}$. For sol-gel samples, it shows that the Raman shift are $1055.3 \mathrm{~cm}^{-1}$ (for samples annealed at $100^{\circ} \mathrm{C}$ and $200^{\circ} \mathrm{C}$ ), $439.696 \mathrm{~cm}^{-1}$ ( for samples annealed at $300^{\circ} \mathrm{C}$ ) and $438.177 \mathrm{~cm}^{-1}$ (for samples annealed $400^{\circ} \mathrm{C}$ ).

The self-combustion samples show the Raman shift at $437.67 \mathrm{~cm}^{-1}$ (annealed at $100^{\circ} \mathrm{C}$ and $200^{\circ} \mathrm{C}$ ), $433.11 \mathrm{~cm}^{-1}$ (annealed at $300^{\circ} \mathrm{C}$ ) and $440.203 \mathrm{~cm}^{-1}$ (annealed $400^{\circ} \mathrm{C}$ ). These two major shifts are known as second order Raman shift are in the same range of reported values which are 323-1120 $\mathrm{cm}^{-1}$ shifts $[12,24]$. It was found that when we further annealed the samples up to $400^{\circ} \mathrm{C}$, the major Raman shift can be observed. Observing all the samples prepared by the self-combustion technique, the major Raman shift approximately at $337 \mathrm{~cm}^{-1}$ can be observed indicating single phase. Both the XRD and the Raman spectra analysis indicated that sol-gel and self-combustion techniques had resulted in single $\mathrm{ZnO}$ phase. 


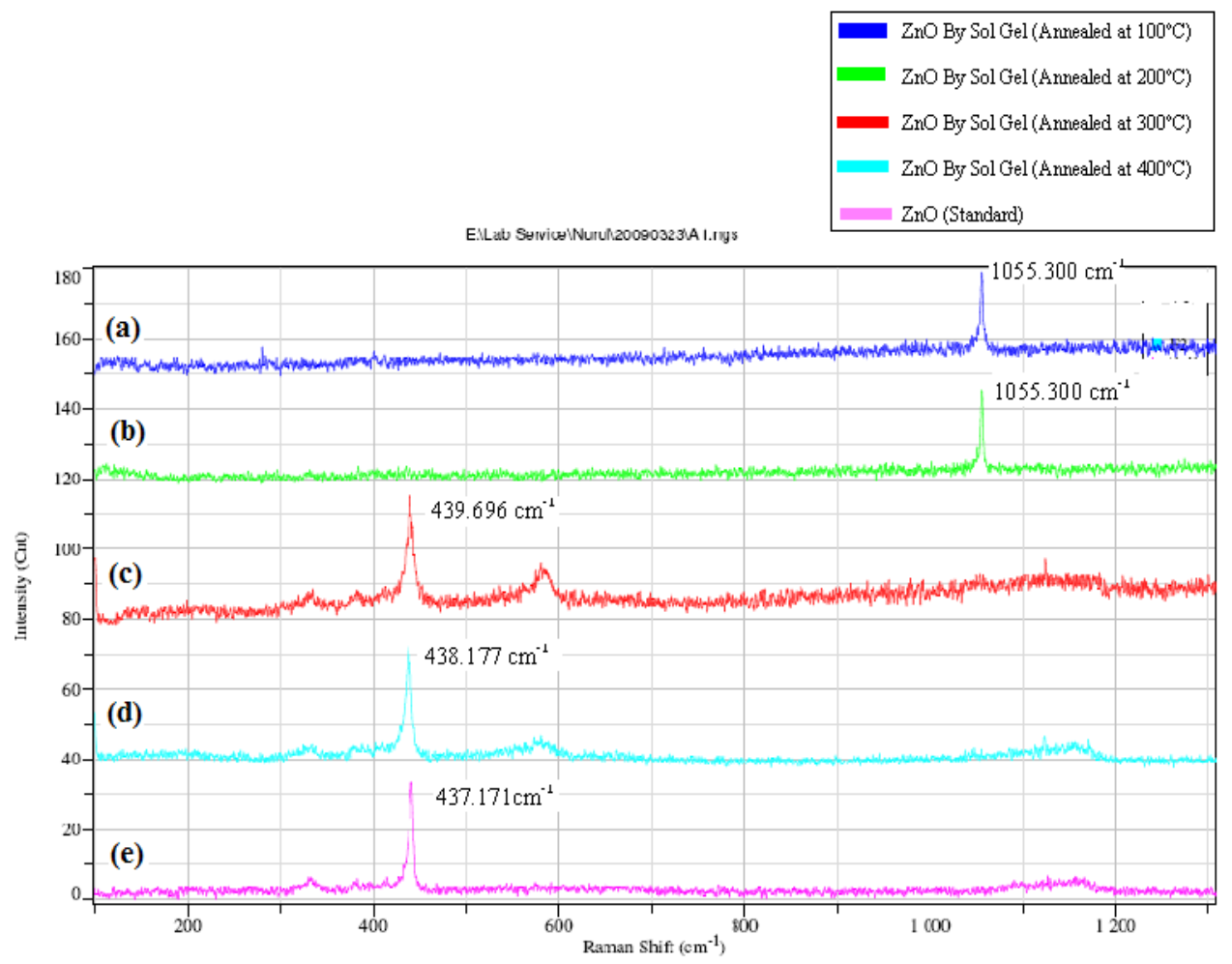

Figure 3. Raman results Sol Gel Technique with Annealing at (a) $100^{\circ} \mathrm{C}$; (b) $200^{\circ} \mathrm{C}$; (c) $300^{\circ} \mathrm{C}$ (d) $400^{\circ} \mathrm{C}$ and (e) Standard Zinc Oxide Raman Shift.

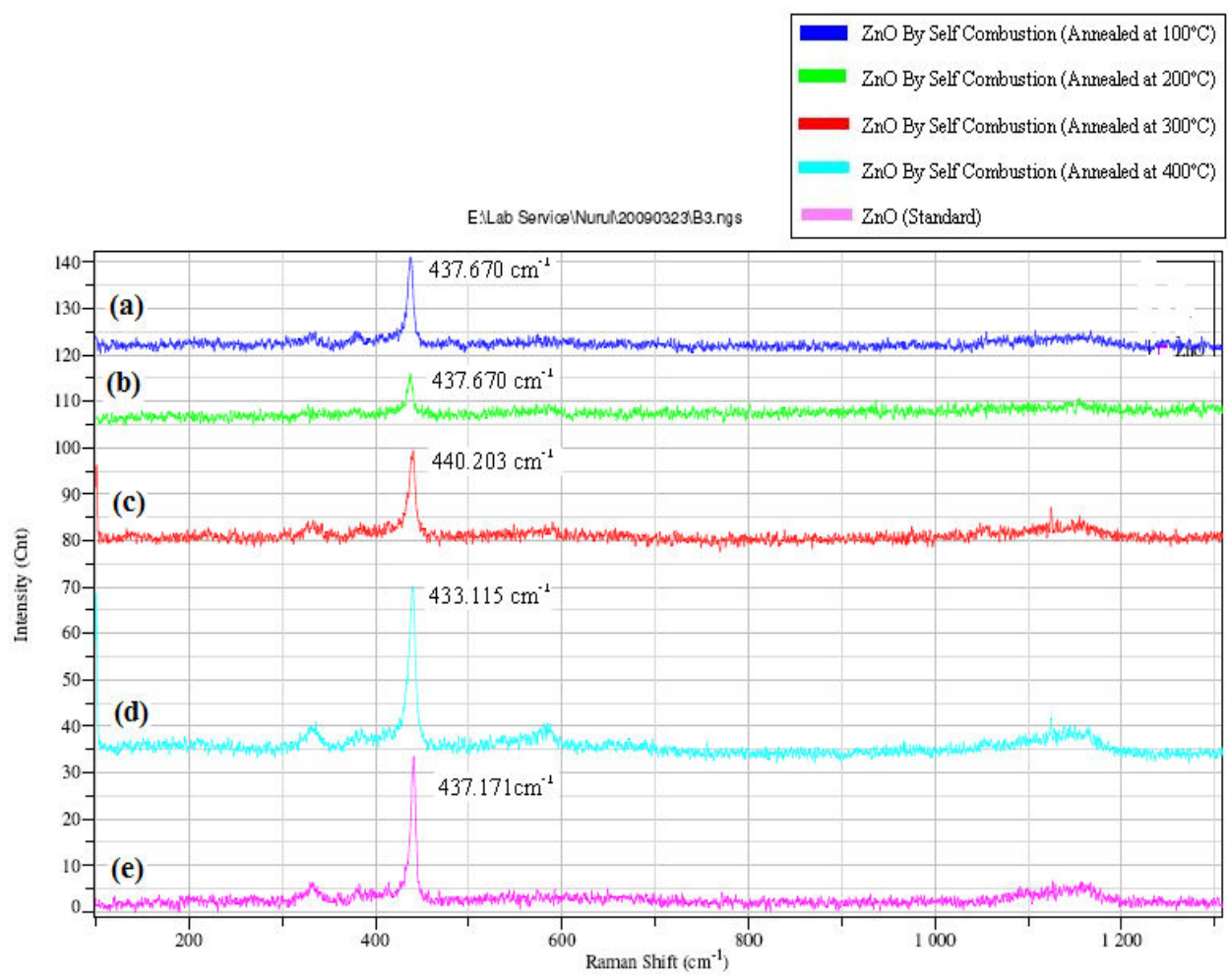

Figure 4. Raman results Self Combustion Technique with Annealing at (a) $100^{\circ} \mathrm{C}$; (b) $200^{\circ} \mathrm{C}$; (c) $300^{\circ} \mathrm{C}$ (d) $400^{\circ} \mathrm{C}$ and (e) Standard Zinc Oxide Raman Shift. 
Scanning Electron Microscope (SEM) Results. The SEM images show that the two different synthesis methods had resulted in different morphologies despite the single phase structure. By using the sol-gel technique, $\mathrm{ZnO}$ flakes were observed. On the other hand, the $\mathrm{ZnO}$ rods morphology was observed when the samples were prepared using the self combustion technique. Generally increasing annealing temperature would result in increasing the grain size [22,23].
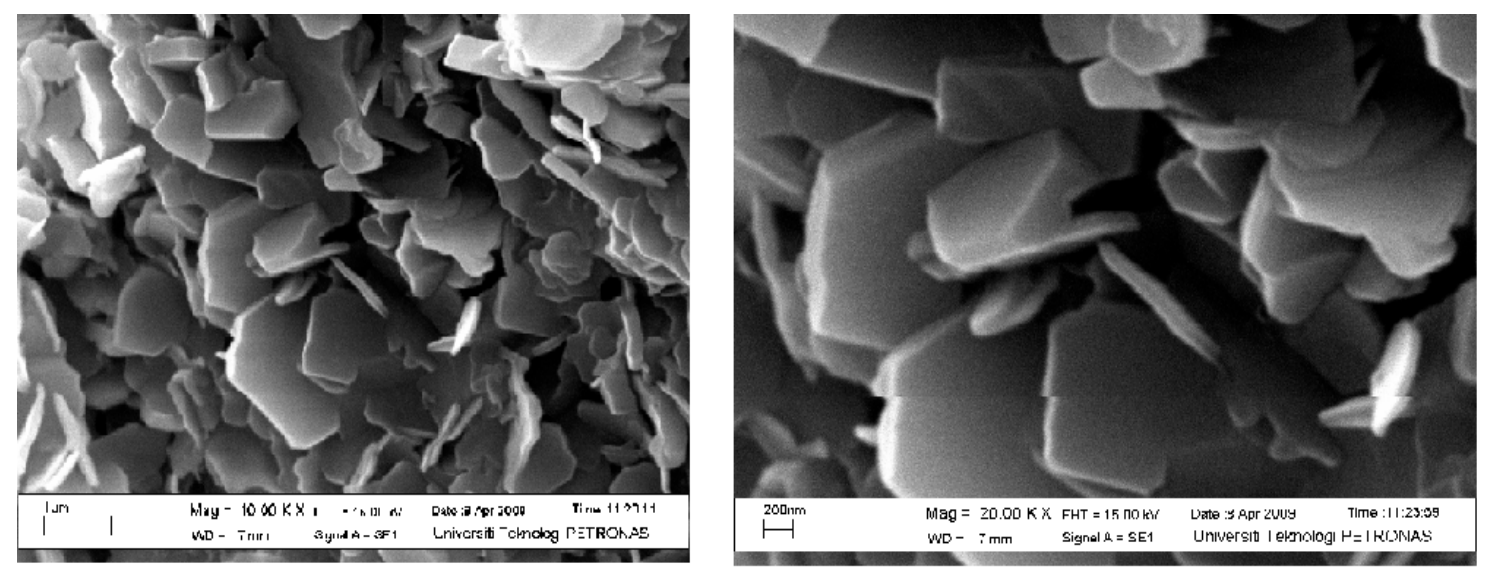

Figure 5. SEM morphology of nanorods at two different magnifications (annealing at $200^{\circ} \mathrm{C}$ ) by using the Sol-Gel technique.
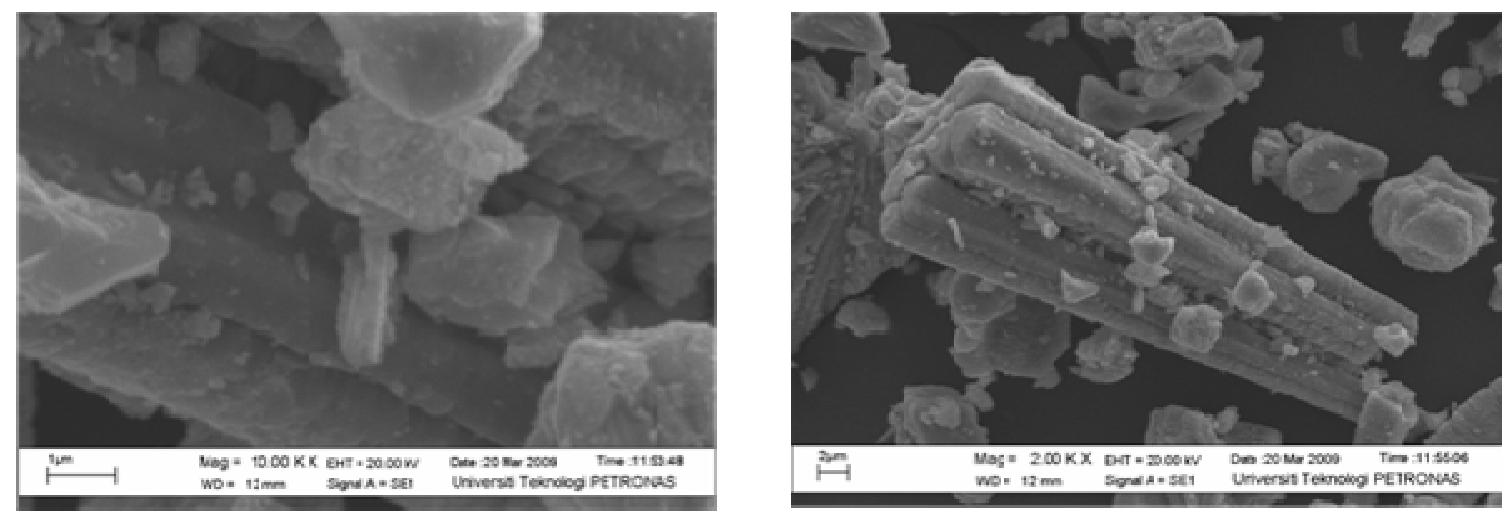

Figure 6. SEM morphology of nanorods at two different magnifications (annealing at $200^{\circ} \mathrm{C}$ ) by using self combustion.

Energy Dispersive X-Ray (EDX) Results. This technique is used to study the elemental properties of the $\mathrm{ZnO}$ samples. Energy dispersive X-ray gives an elemental analysis or analysis of a sample. Referring to the periodic table, the weight of zinc is $80.34 \%$ and oxygen is $19.65 \%$. Referring to Table 2, samples that were prepared using the sol-gel $\left(100^{\circ} \mathrm{C}\right)$ method gives a closer weight percent and atomic percent to the theoretical value. 
Table 2. EDX of Zinc Oxide Samples.

\begin{tabular}{|l|c|c|c|c|c|c|c|c|}
\hline & \multicolumn{2}{|c|}{$\begin{array}{c}\text { Sol Gel at } \\
\text { annealing } 100^{\circ} \mathrm{C}\end{array}$} & \multicolumn{2}{c|}{$\begin{array}{c}\text { Sol Gel at } \\
\text { annealing } 200^{\circ} \mathrm{C}\end{array}$} & \multicolumn{2}{c|}{$\begin{array}{c}\text { Self Combustion } \\
\text { at annealing } \\
100^{\circ} \mathrm{C}\end{array}$} & \multicolumn{2}{c|}{$\begin{array}{c}\text { Self Combustion } \\
\text { at annealing } \\
200^{\circ} \mathrm{C}\end{array}$} \\
\cline { 2 - 9 } & $\mathrm{Zn}$ & $\mathrm{O}$ & $\mathrm{Zn}$ & $\mathrm{O}$ & $\mathrm{Zn}$ & $\mathrm{O}$ & $\mathrm{Zn}$ & $\mathrm{O}$ \\
\hline Weight (\%) & 81.30 & 18.70 & 55.85 & 44.15 & 64.55 & 29.55 & 93.25 & 6.75 \\
\hline $\begin{array}{l}\text { Weight } \\
\text { Percentage } \\
\text { Error (\%) }\end{array}$ & 1.19 & 4.89 & 30.48 & 124.57 & 19.65 & 50.31 & 16.07 & 65.67 \\
\hline Atomic (\%) & 51.56 & 48.44 & 23.64 & 76.36 & 29.69 & 55.54 & 77.16 & 22.84 \\
\hline $\begin{array}{l}\text { Atomic } \\
\text { Percentage } \\
\text { Error (\%) }\end{array}$ & 3.12 & 3.12 & 52.72 & 52.72 & 40.62 & 11.08 & 54.32 & 54.32 \\
\hline
\end{tabular}
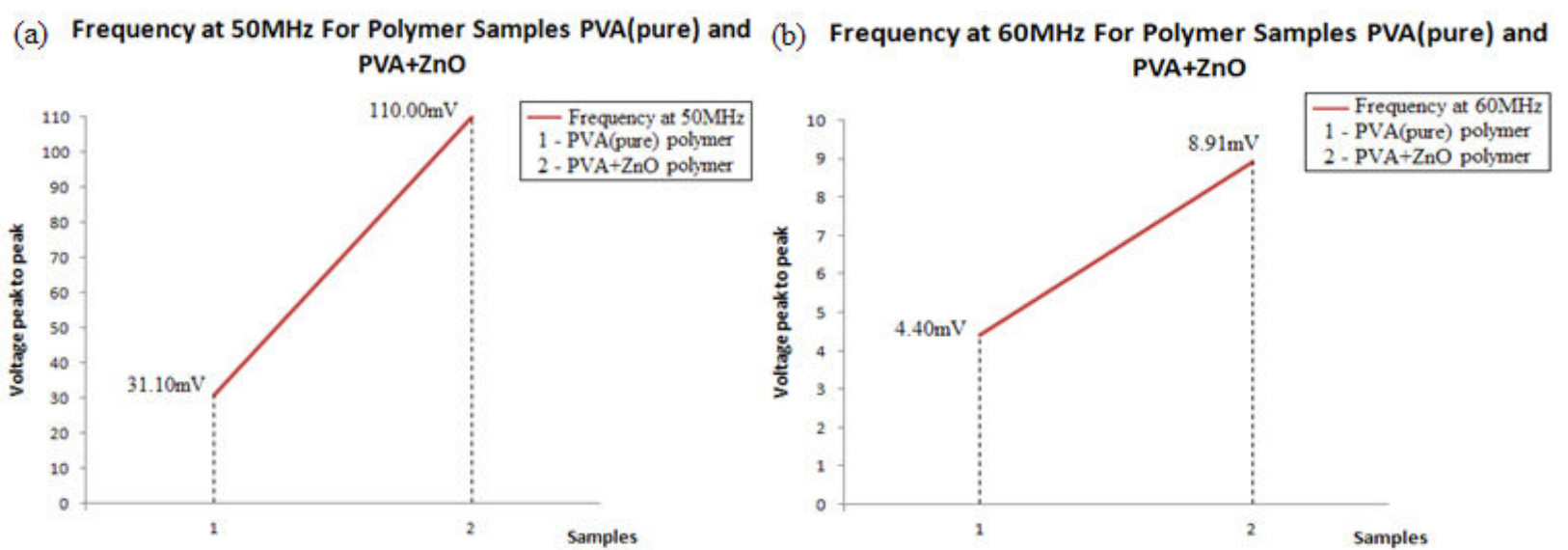

Figure 7. The voltage peak to peak (Vpp) of a detectors (a) Polymer samples PVA(pure) and $\mathrm{PVA}+\mathrm{ZnO}$ is at $50 \mathrm{MHz}$; (b) Polymer samples PVA(pure) and PVA+ZnO at $60 \mathrm{MHz}$.

Observing Figure 7 it shows that PVA $+\mathrm{ZnO}$ polymer sample had shown the higher voltage peak to peak (Vpp) comparing to the PVA polymer without $\mathrm{ZnO}$ as filler. At $50 \mathrm{MHz}$, the PVA polymer sample and the PVA-ZnO polymer sample showed $31.1 \mathrm{mV}$ and $110 \mathrm{mV}$, respectively. The voltage peak to peak was decreased to $4.40 \mathrm{mV}$ for PVA (pure) polymer and $8.91 \mathrm{mV}$ for of PVA+ZnO polymer sample. The different percentage of PVA (pure) polymer and PVA $+\mathrm{ZnO}$ polymer sample are $253.7 \%$ (at $50 \mathrm{MHz}$ ) and $102.5 \%$ (at $60 \mathrm{MHz}$ ) respectively. This preliminary result indicates that PVA-ZnO polymer can be used as an EM detector. Future work will be devoted to improving the fabrication technique of the composite and the weight percentage of the PVA to the $\mathrm{ZnO}$. 


\section{Conclusion}

In this work, single phase $\mathrm{ZnO}$ nanoparticles were successfully synthesized by sol-gel and selfcombustion techniques. It is also concluded that the sol-gel technique has resulted in flake-like microstructure. On the other hand the self-combustion technique resulted in a rod-like microstructure. Besides, the increasing annealing temperature had resulted to an increasing crystallite size. The PVA $+\mathrm{ZnO}$ polymer samples showed a tremendous increase of Vpp indicating the role of $\mathrm{ZnO}$ as an EM detector.

\section{Acknowledgments}

The authors would like to acknowledge Mr. Faizal in the Mechanical Laboratory in which annealing and XRD analysis of the test specimen, Mr. Irwan in the Mechanical Department for taking some SEM images, and Mr. Megat in the Nano Technology Research Laboratory for taking Raman results. We also acknowledge Universiti Teknologi PETRONAS for the STIRF fund to run this project.

\section{References}

[1] X.Q. Zhao, C.R. Kim, J.Y. Lee, C.M. Shin, J.H. Heo, J.Y. Leem, H. Ryu, J.H. Chang, H.C. Lee, C.S. Son, B.C. Shin, W.J. Lee, W.G. Jung, S.T. Tan, J.L. Zhao and X.W. Sun: Appl. Surf. Sci. Vol. 255 (2009), p. 5861.

[2] L. Miao, Y. Ieda, S. Tanemura, Y.G. Cao, M. Tanemura, Y. Hayashi, S. Toh, K. Kaneko:

Sci. Technol. Adv. Mater. Vol. 8 (2007), p. 443.

[3] C.P. Li, Y.Z.L. Guo, H.B. Xu, X.C. Ai and J.P. Zhang: Sol. St. Phen. Vols. 121-123 (2007), p. 805.

[4] L.Q. Zhou, Y. Dai, Y.L. Sun and W. Chen: Sol. St. Phen. Vols. 121-123 (2007), p. 801.

[5] A. Hernandez , L. Maya, E. Sanchez-Mora, E. M. Sanchez: J. Sol-Gel Sci. Technol. Vol. 42 (2007), p. 71.

[6] H. Bahadur, A.K. Srivastava, S.C. Garg, P. Pal and S. Chandra: Frequency Control Symposium and Exposition, 2005. Proceedings of the 2005 IEEE International (2005), p.146.

[7] S. Baruah and J. Dutta: Sci.Technol. Adv. Mater. Vol. 10 (2009), p. 013001.

[8] S. Baruah, C. Thanachayanont and J. Dutta: Sci. Technol. Adv. Mater. Vol. 9 (2008), p. 025009.

[9] K.R. Souza, A.F.F. de Lima, F.F. de Sousa and L.G. Appel: Appl. Catalysis A: General. Vol. 340 (2008), p. 133.

[10] S. Huang, T. Kaydanova, A. Miedaner, D.S. Ginley: J. Undergrad. Res. Vol. 4 (2004), p. 70.

[11] L. Miao, Y. Ieda, S. Tanemura, Y.G. Cao, M. Tanemura, Y. Hayashi, S. Toh and K. Kaneko: Sci. Technol. Adv. Mater. Vol. 8 (2007), p. 443.

[12] P. Puspitasari, N. Yahya, N.A.M. Zabidin, S.M.S.N.S. Zahari, and N.A. Ahmad., Synthesis and Characterization of Zinc Oxide Nanoparticles by Self-Combustion Technique, published in American Applied Science and Proceeding of International Conference of Nanoscience at UiTM, 2008.

[13] H.L. Xia and F.Q. Tang: J. Phys. Chem. Vol. 107 (2009), p. 9175.

[14] M.P. Manoharan, A.V. Desai, G. Neely, and M.A. Haque: J. Nanomaterials (2008) on-line.

[15] Y.J. Kwon, K.H. Kim, C.S. Lim and K.B. Shim: J. Ceram. Proc. Res. Vol. 3 (2002), p. 146.

[16] T.G. Altincekic and I.Boz: Bull. Mater. Sci.Vol. 31 (2008), p. 619.

[17] H. Liang and R.G. Gordon: J. Mater. Sci. Vol. 42 (2007), p. 6388.

[18] P.Y. Wu, J. Pike, F. Zhang and S.W.Chan: Int. J. Appl. Ceram. Technol. Vol. 3 (2006), p. 
[19] D.K. Jain and J.C.Garg., Electrical Conductivity of Zinc Oxide at High Fields, Dept. Physics, University of Rajasthan, Jaipur, (1979).

[20] N. Yahya, A.S.M.N. Aripin, A.A. Aziz, H. Daud, H.M.Zaid, L.K.Pah and N. Maarof: Am. J. Eng. Appl. Sci. Vol. 1 (2008), p. 53.

[21] V. Noack and A. Eychmuller: Chemistry of Mater. Vol. 14 (2002), p. 1411.

[22] H. D. Reitz, S. Kumar, X.Bi, and N. Kambe, Zinc Oxide Particles, United States Patent, (2008).

[23] Z. Fan and J.G. Lu: J. Nanosci. Nanotechnol. Vol. 5 (2005), p. 1561.

[24] A. Khan., Synthesis, Characterization and Luminescence Properties of Zinc Oxide Nanostructure, PhD thesis, Ohio University, 2006. 